\title{
Animation in Science Learning With Brain Based Learning Models to Improve Student Learning Outcomes
}

\author{
Ni Kadek Ayu Mita Wulansari1 ${ }^{*}$, Ni Ketut Suarni² I Wayan Widiana ${ }^{3}$
}

123 Universitas Pendidikan Ganesha, Singaraja, Indonesia.

\author{
A R T I C L E I N F O \\ Article history: \\ Received 18 March 2020 \\ Received in revised form \\ 30 April 2020 \\ Accepted 5 May 2020 \\ Available online 15 May \\ 2020
}

\section{kata kunci:}

BBL, animasi, hasil belajar

IPA

keywords:

$B B L$, animation, science

learning outcomes

\begin{abstract}
A B S T R A K
Permasalahan penelitian ini yaitu: kurang maksimalnya penguasaan pendidik terhadap model dan media pembelajaran inovatif, siswa dibebani dengan banyak materi tanpa ada jeda untuk memberikan waktu kepada otak untuk memproses materi yang diberikan, pembelajaran berlangsung kurang efektif serta terkesan membosankan, kurangnya partisipasi serta keaktifan siswa dalam proses pembelajaran, pembelajaran yang berlangsung di kelas kurang bervariasi sehingga berdampak terhadap hasil belajar siswa. Sehingga penelitian ini bertujuan untuk mengetahui pengaruh model brain-based learning berbantuan animasi terhadap hasil belajar IPA. Penelitian ini merupakan penelitian eksperimen semu, dengan desain Nonequivalent Control Group Design.Populasi penelitian ini adalah seluruh kelas V SD dengan jumlah siswa 129. Sampel dalam penelitian ini adalah siswa kelas VA SD Lab Singaraja yang berjumlah 70 siswa. Metode pengumpulan data dalam penelitian ini adalah metode tes dalam bentuk tes pilihan ganda yang sudah divalidasi. Data dianalisis menggunakan uji-t. Hasil analisis data diperoleh $t_{\text {hitung }}=9,66$ pada
\end{abstract} taraf signifikansi $5 \%$ dan $d b=68$ diperoleh nilai tabel $=2,00$ sehingga thitung $=9,66>$ tabel $=2,00$. Dengan demikian dapat disimpulkan bahwa terdapat pengaruh positif model brain based learning berbantuan animasi terhadap hasil belajar ipa. Model brain based learning berbatuan animasi dapat diaplikasikan pada pelajaran ipa di sekolah dasar sebagai upaya utuk meningkatkan hasil belajar siswa secara maksimal pada pelajaran ipa.

\begin{abstract}
A B S T R A C T
The problems of this study are: the lack of maximum mastery of educators on innovative learning models and media, students are burdened with a lot of material without any pause to give the brain time to process the material provided, learning is less effective and well thought out, discussed useful and active students in the learning process, learning that takes place in the class that is less influential on student learning outcomes. The brain-based learning model of animation-assisted learning of science learning outcomes. This research is a quasi-experimental study, with the design of Nonequivalent Control Group Design. The population of this research is all of the fifth-grade elementary school with 129 students. The method of collecting data in this study is a test method in the form of a multiple-choice test that has been validated. Data were analyzed using a $t$-test. The results of data analysis obtained $t$-count $=9.66$ at a significance level of $5 \%$ and $d b=68$ obtained $t$-table $=2.00$ so $t$-count $=9.66>t$-table $=2.00$. Thus it can be concluded that there is an influence of an animation-based brain-based learning model on science learning outcomes. Animated brain-based learning model can be applied to science lessons in elementary school as an effort to improve student learning outcomes optimally in science learning.
\end{abstract}

\section{Introduction}

Natural science is a large part of human mental activity and practice to produce knowledge. The science learning process should be designed. Students do not feel pressured in learning and also become active both physically and mentally. Sujana (2014) the importance of science subjects given to students. Science can understand how people interact with the environment and understand how nature works. How to survive and improve human life if learned correctly. Setiawan (2019), states that the implementation of primary school learning, learning must emphasize modern pedagogical dimension and prioritize personal experiences through scientific processes. The scientific process is expected to have a positive impact on learning outcomes. Sinar (2018) states that learning outcomes are the results of a person after they have finished learning from several subjects, which is proved

Copyright (c) Universitas Pendidikan Ganesha. All rights reserved.

${ }^{1}$ Corresponding author.

E-mail addresses: mithawulan388@gmail.com¹(Mita),niketut.suarni@undiksha.ac.id ${ }^{2}$ (Suarni),wayan widiana@yahoo.co.id ${ }^{3}($ Widiana) 
through the test results in the form of learning outcomes. In his research, learning in the classroom still tends to be textual and lecture methods, students not allowed to optimize their brainpower with the challenges they have to solve, so students are lazy to think. Davi et al. (2017) who also found that the teaching methods of teachers who were only guided by the thematic books provided by the Government caused the mindset of students to understand the contents of the material to be narrow. It is proven from the results of the 2018 PISA (Program for International Students Assessment) which shows that the competency of Indonesian students is still below the average.

It supported by the findings that science learning in Gugus iX Kecamatan Buleleng, Kabupaten Buleleng still teacher-centered. Initial observations and interviews show that teachers rarely use the media or teaching aids for science lessons even though in schools there are media devices or science props and are not accustomed to involving students in conducting experiments so that the lack of students and teacher skills. The lack of student involvement makes students less active and passive in learning in the classroom. In addition, the learning model is still centered on the teacher and the learning activities carried out in the classroom tend to be monotonous, and less varied, thus making students bored quickly. The students' understanding of ability also varies with the learning given. The diverse abilities of students lead to different student learning outcomes. This reflected in the midterm test scores in the fifth grade of the elementary school in Kecamatan Buleleng, Kabupaten Buleleng. When collected documents, it was found that the UTS grades of students in learning science are very diverse. Based on Khamin (2018) it can be seen that from 128 students there were 6 students categorized need guidance, 59 students were categorized as sufficient, 49 students were categorized as good and 14 students were categorized as very good. So that it can be seen from the number of students as many as 128, students with the most number ie 49 students are in the sufficient category. Khamin (2018) states that the content of lessons starts from 75. So, it needs to increase from sufficient criteria to higher criteria to assess the extent of the performance in the learning process that has been followed.

In line with the results of interviews and observations conducted in the fifth grade of Elementary School Gugus IX, Kecamatan Buleleng, Kabupaten Buleleng on October 28 and 31, 2019, pointed to the lack of participation and student activeness in the learning process and teachers also still use conventional learning models, so learning is still centered on the teacher. Learning takes place less effectively and boring because of the lack of teachers' mastery of innovative learning models and the media used by teachers is less varied. The teacher is more dominant to use the blackboard as a learning medium without using other media such as animation media, so there is no pause to give the brain time to process the material provided. It will make students bored with the lessons, and the learning that takes place in class is less varied so that it has an impact on learning outcomes.

This situation will affect the level of student's learning success. If learning like this continues to be applied, it will lead to boredom for students which will have an impact on the low learning outcomes of science students which can be seen from the large number of students who are in the sufficient category based on the K13 elementary school assessment guide. Therefore, teachers are required to be able to choose appropriate learning activities, so students avoid boredom, and create conditions for learning that are interactive, effective, and efficient.

Gowasa et al. (2019) found that there was a positive influence on the ability to think at a higher level of science learning. Rahayuni (2016) in his research found a strong correlation between critical thinking skills and scientific literacy. Aryani et al. (2019) found a positive attitude of students towards science learning. The research will develop science learning to improve learning outcomes. One way to improve science learning outcomes for students is to apply innovative learning models. Afandi (2013) states that the learning model is a framework that describes systematic procedures in learning, objectives, syntax, learning environment, and classroom management. The learning model serves as a guide for learners and instructors in developing and implementing learning activities. Learning models have several types, such as contextual learning models, cooperative learning models, and also innovative learning models. The innovative learning model is a learning process that is designed differently from learning done by the teacher.

Based on these problems, the learning model thought to influence science learning outcomes is a brain-based learning model assisted by animation. Jensen (2011) states that "The model of brainbased learning is a concept for creating learning with an orientation towards empowering the potential of students' brains". Based on its characteristics, brain-based learning is a learning model that involves the functions of the left brain and right brain. In the learning process, students required to think creatively how to maximize the ability of the left brain and right brain during the learning process takes place (Rosita \& Nur, 2016). 
According to ElAdl (2019), Brain-based learning can improve student learning through challenges given. Inocian (2015) reveals that brain-based theory is one of the theories that is well used by educators in the learning process. Winter (2019) states Learning will be more effective in real-life related to life experiences using brain-based learning models. In line with this, Yasar (2017) also revealed that brain-based learning is a student-centered approach that considered to help teachers improve students' cognitive structures and facilitate their learning. Hapsari (2019) argues that animation has the aim to explore the depth of students' knowledge about the material because the video can be played back. According to Purnama (2016), the advantages of a brain-based learning model are that it can create a learning environment that challenges students' thinking abilities, creates a pleasant learning environment, and creates an active and meaningful learning situation for students (active learning). Salem (2017) revealed that brain-based learning is a strategy that implements teaching practices through three learning techniques; relaxed alertness, regulated immersion, and active processing. Brain-Based Learning is very effective when applied at school. This is evidenced by research conducted by Rulyansyah (2018) entitled "Development of Thematic Learning Models Based on Brain-Based Learning" shows that brain-based learning can improve students 'conceptual understanding abilities and efforts to empower students' overall brain potential.

Some studies that find that the brain-based learning model influences learning outcomes are research conducted by Widiasih (2018) with the title "The Effect Of Brain-Based Learning On Second Grade Junior Students' Mathematics Conceptual Understanding On Polyhedron". The results of this study indicate that motivation arises for students to understand the concept of learning so that it will be achieved as well as optimizing students' conceptual understanding of mathematics. The research conducted by Widiasih (2018) is related to the research to be studied, which is equally studying the brain-based learning model. Furthermore, research conducted by Koşar \& Bedir (2018) with the title "Improving Knowledge Retention Via Establishing Brain-Based Learning Environment". The results of this study indicate that the brain-based learning model can help participants retain the knowledge they know so far. The study conducted by Kosar is related to the research conducted at this time, which is using a brain-based learning model. Research conducted by Sani et al. (2019) with the title "Using Brain-Based Learning to Promote Students' Concept Mastery in Learning Electric Circuit". The results of this study indicate that the brain-based learning model can improve students' mastery of concepts on the topic of electrical circuits. The research that will be conducted at this time is slightly different from the research conducted by Sani, that is, the research that will be examined now will examine the learning outcomes of Natural Sciences and the equation using brain-based learning models.

Shabatat \& Al-Tarawneh (2016) also argue that this strategy is based on the generation of ideas on topics, where students are allowed to think freely without intervention by the teacher. This strategy is applied to small groups or classes as a whole. From some of the research that has been carried out, it can be assumed that the model of brain-based learning assisted with animation is one alternative to make the atmosphere in the classroom more alive. There are many animations that elementary students can watch. But this animation must be able to educate and provide lessons in a way that is not boring. This animated, brain-based learning model creates an active and meaningful learning situation for students. By watching animation students do not only imagine what the teacher has to say, but to build their knowledge through an active learning process that they do themselves. Build learning situations that allow all members of the student body to move optimally, for example, students 'eyes are used to observe animation, students' hands move to write what has been observed from the animation, students 'feet move to follow the game in learning, students' mouths actively ask questions and discuss, and the activities of other productive limbs. Referring to the concept of educational constructivism, student learning success is determined by how capable students build knowledge and understanding of learning material based on the learning experiences they experience themselves.

According to Dewi et al. (2017), animation media can utilize two senses namely the sense of sight and sense of hearing, so that students more easily understand an abstract concept that becomes more concrete. Animation media contains cartoon images so that the messages and information conveyed are more interesting to students, students can understand a concept as a whole, not only as knowledge but can also be applied in the learning process activities and everyday life. Malkoc (2017) believes that Animation is a presentation technique that allows one to describe the results of a simulation. According to Chujitarom \& Piriyasurawong (2017) animation techniques can impress watchers with a sequence of moving images, generally hand drawings or computer graphics. The human eye sees through the persistence of vision and images come to life continuously. Kaushal \& Panda (2019) revealed that animation-based teaching styles are effective for topics that require 
change over time and space. Dervić et al. (2019) in his research revealed that using animation can produce more intensive involvement with cognitive processes that are relevant for learning. Dikmenli et al. (2018) in his research revealed that the use of animation in learning activities has a positive effect.

The objectives to be achieved in this study are to find out the significant effect of animationbased brain-based learning models on the learning outcomes of fifth-grade science students in elementary school $2019 / 2020$. So the focus of this research is limited to the low learning outcomes of science students.

\section{Method}

This research was an experimental study considering that not all variables (symptoms that arise) and the conditions of the experiment can be regulated and controlled tightly, so this research is categorized as quasi-experimental research. The experimental design used is a non-equivalent posttest only control group design. The non-equivalent post-test only control group design pattern is presented as follows.

The population in this study were all fifth-grade elementary school Gugus XI Kecamatan Buleleng Kabupaten Buleleng Academic Year 2019/2020 which amounted to 5 classes, fifth grade A Singaraja Lab Elementary School with 35 students, fifth grade B Singaraja Lab Elementary School with 35 students, fifth-grade SDN 1 Kampung Anyar, which has 17 students, fifth grade in SDN 3, Kampung Anyar which has 17 students, and fifth-grade SDN 1, Kampung Bugis, which has 25 students. In this study, the sample selection technique used to select the experimental class and the control class by random sampling technique. Five classes will be randomized to determine the class to be used as the control and experiment class. Fifth grade A SD Lab Singaraja which amounted to 35 students as an experimental group and fifth grade B SD Lab Singaraja amounted to 35 students as a control class was given conventional model treatments.

The research procedure consisted of the preparation phase, the implementation phase, and the final stage of the study. In the preparatory stage Asking for permission from the principal to make observations, conduct discussions with the teacher about learning science in fifth grade, to find out more information and know the characteristics of these students, determine the research sample of the available population by looking at the number of students, conduct an equivalence test using the Anava A test to find out that the two classes are truly equivalent, determine learning material in accordance with the basic competencies of natural science subjects in fifth grade. Designing research instruments, at this stage, the researcher designs an (RPP), designing a test that will be used as a post-test (final test), designing an assessment sheet, and consults the research instrument that has been prepared to the supervisor, carried out an expert test (judgest), revises the research instrument who have been tested and fixing the instruments that have been tested, prepare learning media to be used.

At the implementation stage, applying treatment, this activity is carried out by applying animation-based brain-based learning models in the experimental class and conventional models in the control class. Furthermore, at the final stage of the research that is conducting a final test (posttest) with the measured basic competence is about knowledge, and provide tests in the experimental class and control class. The test is intended to determine the competence of students' science knowledge and then analyze the research data and conduct a hypothesis test. There are 2 variables in this study, the independent variable is a brain-based learning model assisted with animation, while the dependent variable is the science learning outcomes.

The data collected in this study were the results of science learning for fifth-grade students of the Gugus XI Elementary School in Buleleng academic year 2019/2020. The data collection of science learning outcomes in the cognitive domain in this study uses the test method. A multiple-choice test will be given at the end of the study (post-test). The test used is a multiple-choice test with one correct answer. The test was arranged based on the lattice of questions that have been made in accordance with $\mathrm{BC}$ and indicators. After the lattice is made, before it is used to measure the results of science learning, first a lattice in the form of an instrument will be tested. The instrument test is a validity test, test, reliability, different power, and difficulty level.

The data obtained were then analyzed using descriptive statistics and inferential statistics. Statistics were used to determine the quality of learning outcomes, both the experimental group and the control group. The descriptive statistical analysis used is mean, median, mode, standard deviation, and variance. To determine the level of quality of science students' learning outcomes, the average score of each variable is connected using the ideal average criteria (Mi) and ideal standard deviation (SDi). Before conducting a hypothesis, test using the t-test, a prerequisite test is performed first. The 
prerequisite tests that must be met are the normality test and the variant homogeneity test. After the prerequisite tests are met, it is continued with hypothesis testing using t-test analysis which is calculated manually and using Microsoft Excel 2007 for Windows.

\section{Result and Discussion}

Based on the results of the calculation of the description of the data obtained by the average score of the science learning outcomes of the experimental group students 21.49 , while the control group 18.69. The median of the natural science learning outcomes of the experimental group was 22, while the control group was 19 . The natural learning outcomes of the experimental group was 22 , the control group was 18. The standard deviation of the learning outcomes of the experimental group was 1.25 while the control group was 1.13 . The variance of science learning outcomes in the experimental group was 1.55 while the control group was 1.28 . The table that shows the description of the data can be seen in table 2 .

Table 2. Description of Experiment Group and Control Group Data

\begin{tabular}{ccc}
\hline Variance & Experiment & Control \\
\hline Maximum Score & 24 & 21 \\
Minimum Score & 19 & 16 \\
Mean & 21,49 & 18,69 \\
Median & 22 & 19 \\
Modus & 22 & 18 \\
Standard Deviation & 1,25 & 1,13 \\
Variants & 1,55 & 1,28 \\
\hline
\end{tabular}

Table 2 shows the results of the calculation of descriptive statistics posttest scores of students' natural science learning outcomes obtained an average of 21.49 experimental group learning outcomes, while the average learning outcomes of the control group was 18.69. These data show that the science learning outcomes of the experimental group are higher than the control group. Whereas judging by the acquisition of scores, the highest score in the experimental group was 24 out of 25 questions given, and in the control group, the highest score was 21 out of 25 questions. So for the tendency for the classification of science learning outcomes of fifth grade A LAB elementary school LAB Singaraja and fifth grade B LAB elementary school Singaraja, a criterion with a scale of five was used. Criteria with a scale of five experimental group learning outcomes included in the criteria are very high, with an average score was 21.49 natural science learning outcomes, so it is in the range of 18.76 $\leq x \leq 25$, while in the control group included in the criteria either by an average 18.69 , so it is in the range of $14.59 \leq \mathrm{x}<18.76$.

Table 3. Test Results Normality of Science Learning Outcomes Data Distribution

\begin{tabular}{clccc}
\hline No & Sample & $\chi^{2}$ & $\begin{array}{c}\text { c } \\
\text { c2count } \\
\text { table }\end{array}$ & Status \\
\hline 1 & Experiment class & 4,39 & 7,815 & Normal \\
2 & Control class & 0,83 & 7,815 & Normal \\
\hline
\end{tabular}

Based on the results of the normality of science learning outcomes of the experimental group and the control group in table 4, it can be seen that the X2 count in the experimental group was 4.39 at a significance level of $5 \%$ with a degree of freedom 3 and it was known that X2table was 7,815, this means that hit2hit $<\mathrm{X} 2 \mathrm{tab}$, then the post-test results of the experimental group students were normally distributed. Whereas the X2 count of the control group was 0.83 at the $5 \%$ significance level with a degree of freedom 3 and it was known that tab2 tab $=7.815$, this means that hit 2 hit $<\mathrm{X} 2 \mathrm{tab}$ then the results of the control group's post-test data were normally distributed. Based on the results of the post-test results of the experimental group and the control group were normally distributed. A homogeneity variance test is performed to show that two or more sample data groups come from populations that have the same or homogeneous variance. The homogeneity test of the variance data of 
the science learning outcomes of the experimental group and the control group was obtained fcount = 1.21. This value is then consulted with the f-table price with a significance level of $5 \%$ with degrees of freedom df $1=1$ and df2 $=69$. So the results of the $\mathrm{f}$-table analysis $=3.98$. So fcount $1.21<\mathrm{ftabel}=3.98$, it can be said that the learning outcomes of the experimental group and the control group have homogeneous variance.

From the prerequisite test results, namely the normality and homogeneity test, it was obtained that the data of the science learning outcomes from the experimental group and the control group were normally distributed and homogeneous.

From the analysis results Tcount $=9.66$ and $t$-table $=2.00$ at a significance level of $5 \%$ with $\mathrm{db}$ $=\mathrm{n} 1+\mathrm{n} 2-2=(35+35-2)=68$. Because Thitung $=9.66>\mathrm{t}$-table $=2,00$ then $\mathrm{H} 1$ was accepted stating that there were significant differences between groups of students who were taught using the Animation-assisted Brain-Based Learning model and students who were taught using the conventional model of the science learning outcomes of fifth-grade students in Elementary School 2019/2020 Academic Year.

The results of a descriptive analysis conducted on the experimental group and the control group showed that the average value of students who were taught using the Animation-assisted BrainBased Learning model ( $\bar{X}=21.49$ ) with the highest score 24 and the lowest score 21 , according to the analysis of the results learn science students in the experimental group. Average results learned by conventional learning $(\bar{X}=18.69)$ with the acquisition of the highest score was 21 and the lowest score of 16 , according to the analysis of the science learning outcomes in the control group. Based on the criteria of the average ideal standard deviation of the experimental group that was taught using the Brain-Based Learning model assisted by Animation was at very high criteria and the average in the control group that was taught using the conventional model was at a high criterion.

Based on the field findings that the author obtained during the research, it can be seen that the teaching and learning process is more effective in the classroom learned by Animation-assisted BrainBased Learning models compared to students who are taught with conventional learning models. Based on the acquisition of science learning outcomes in the two groups it can be seen that the two groups that initially had equal abilities, then after learning to use different models the acquisition of science learning outcomes experienced differences. The difference is due to the learning applied in the experimental group has advantages compared to the model applied to the control group. Assisted Brain-Based Learning Model Animation is a model that considers how to maximize the way the brain works optimally and optimally. As is well known the brain-based learning model is learning that is designed according to the way the brain works to be able to maximize the ability of the left and right brain because the brain is a parallel process that can perform several activities at the same time. This is in line with what was stated by Jensen (2011) that the brain-based learning model is a concept for creating learning oriented to the empowerment potential of students' brains. According to Purnama (2016), the advantages of brain-based learning model learning are that it can create a learning environment that challenges students' thinking abilities, creates a pleasant learning environment, and creates an active and meaningful learning situation for students (active learning). In addition to choosing the right learning model, the application of learning media is also very important to do. One of the learning media that is suitable to be combined with a brain-based learning model is the animation media. The application of this brain-based learning model assisted by animation media is a suitable combination applied in natural science subjects, especially science learning in elementary schools. Since elementary school students are at a concrete operational level, students will experience some difficulties in learning several abstract concepts. Chujitarom \& Piriyasurawong (2017) stated that animation techniques can impress viewers with moving image sequences. For this reason, the application of the brain-based learning model assisted by this animation media will help students overcome some of these difficulties. In this case, the animation media can help align the workings of students' brain hemispheres. The use of animation media aims to make it easier for students to remember the content of the material because the brain can correct the animation that has been observed and helps students to pay attention to the content provided by the teacher. The utilization of these media will optimize the work of the right brain in the learning process. Learning by using Animation-based Brain-Based Learning models can increase student involvement. The learning process carried out can actively involve students in following the stages of learning. According to Jensen (2011) there are seven stages of the Brain-Based Learning model, namely 1) Pre-exposure, 2) Preparation, 3) Initiation and Acquisition, 4) Elaboration, 5) Incubation and Encoding of Memory, 6) Trust Verification and Checking, 7) Celebration and Integration. 
By applying the Brain-Based Learning model assisted with Animation students become ready to accept learning because at the beginning of learning students are given an overview of animation in accordance with the material to be studied, so that with the animation students become more ready to accept learning, and can create a more enjoyable learning environment, attract students' attention and focus on the material that will be received to create an active and meaningful learning situation for students with the animation. Learning that applies Animated Brain-Based Learning models can arouse students' enthusiasm for participating in learning and increase student activity in the learning process. The enthusiasm of the students was formed from the first phase, namely the Pre-exposure phase when the students were given a review in the form of Animation, the students were very enthusiastic about paying attention to the animation provided as well as the stimulus in the form of questions related to the animation that had been given. When students already have e in learning and focus is directed, students will take the learning process seriously. This also appears to students, because it is seen when the teacher does an elaboration activity that is giving LKPD, students do it seriously, and at the Verification and Checking stage Trust students are very enthusiastic and eager to deliver the results of their work.

This study proves that the animation-based brain-based learning model has a positive effect on student learning outcomes in science. Brain-based learning models if combined with animation can affect the learning outcomes of science, this is seen when given a review or at the beginning of learning. The animation is given at an early stage of learning, namely the pre-exposure stage. By giving the animation, it gives the brain a review of new learning before it is explored. By giving an overview in the form of animation students better understand the learning objectives they will learn so that during the learning process students can be actively involved in the learning process. In this study, it was found that the brain-based learning model assisted with animation is a condition that is more in accordance with students to maximize the workings of the brain so that it can improve the learning outcomes of science. Adiansha et al. (2018) revealed that this brain-based learning model is learning by observing the brain. Students can freely use their knowledge to solve problems that have never been faced, and have more responsibility for learning along with the increase in their experience and knowledge. In an animation-based brain-based learning model, students are more ready to accept learning, can create a learning environment that is more fun, attracts the attention of students, and focuses on the material to be received to create an active learning situation for students to participate in learning. The research conducted will be meaningful for students with the animation. This is in line with Hapsari et al. (2019) which revealed that the animation had the aim of exploring the depth of students 'knowledge about the material because the video could be played back. Learning using the Brain-Based Learning model assisted with Animation can arouse students' enthusiasm for participating in learning and increase student activity in the learning process. In line with this Erhan (2016) revealed that the animation watched by students made them enjoy the lesson and became active participants in the listening process.

These findings have implications, namely, to improve the learning outcomes of science, an animation-assisted brain-based learning model can be implemented by providing a review at the beginning of learning so that students are better prepared to accept learning. The results of this study are strengthened by research conducted by Aryani et al. (2019) in his research found a positive influence on students' learning of science. Research conducted by Fitriani (2019) shows a significant difference between students who are taught with learning models with the title research on the influence of Brain-Based Learning models and students who are taught with conventional learning, research conducted by Duskri et al. (2019) which shows that there are significant differences between students who are taught with the Brain-Based Learning model and students who are taught with conventional learning, as well as research conducted by Rosita \& Nur (2016) which shows there are significant differences between students who are taught with the Brain model Based Learning and students who are taught with conventional learning.

\section{Conclusion}

Based on the results of hypothesis testing and discussion, it can be concluded that there is a significant influence on the animation-based brain-based learning model on the learning outcomes of fifth-grade science students in Elementary School 2019/2020 Academic Year. This can be seen from the average score of students' science learning outcomes and t-test results. The average score of science learning outcomes for groups of students who were taught with the Animation-assisted BrainBased Learning model was 21.49 which was in a very high category while the average score of science learning outcomes for groups of students who were taught using conventional models was 18.69 who 
were in the high category. Based on the results of t-test calculations, it is known that $t$-count $=9.66$ and $\mathrm{t}$-table with $\mathrm{db}=68$ at a significance level of $5 \%=2.00$. This means that the $\mathrm{t}$-count is greater than $\mathrm{t}$ table ( $\mathrm{t}$ count $>\mathrm{t}$ table), so $\mathrm{H} 0$ was rejected and $\mathrm{H} 1$ is accepted.

Based on the conclusions above the suggestions that can be given to several parties include, (1) to the teacher, teachers should be able to continue learning with Animation-assisted Brain-Based Learning models with some modifications to suit the subject matter, conditions, schools, and students, (2) It is suggested that the principal introduce and give s to teachers to apply innovative learning models especially animation-based brain-based learning models to improve students' science learning outcomes, (3) to other researchers who are interested in conducting further research on Brain-Based Learning models assisted with Animation in the field of Natural Sciences and other lessons to improve student learning outcomes in Natural Sciences This research is a material consideration for the improvement and refinement of research to be conducted.

\section{References}

Adiansha, A. A., Sumantri, M. S., \& Makmuri, M. (2018). Pengaruh model brain based learning terhadap kemampuan komunikasi matematis siswa ditinjau dari kreativitas. Premiere Educandum : Jurnal Pendidikan Dasar Dan Pembelajaran, 8(2), 127.

Afandi, Muhamad, D. (2013). Model dan Metode Pembelajarandi Sekolah. Unissula Press.

Afib Rulyansyah, U. H. (2018). Pengembangan model pembelajaran tematik integratif berdasarkan brain based learning. Tarbiyatuna : Kajian Pendidikan Islam, 2(educational research), 40-57.

Aryani, D., Astalini, A., \& Kurniawan, D. A. (2019). Identifikasi Sikap Siswa Terhadap Mata Pelajaran IPA di Smp Se Kabupaten Muaro Jambi. Jurnal Pijar Mipa, 14(2), 111-127.

Chujitarom, W., \& Piriyasurawong, P. (2017). Animation Augmented Reality Book Model (AAR Book Model) to Enhance Teamwork. International Education Studies, 10(7), 59.

Davi, F. S., Susilo, H., \& Ramli, M. (2017). Penerapan Model Brain Based Learning Dengan Mind Map Untuk Meningkatkan Kemampuan. 249-252.

Dervić, D., Đapo, N., Mešić, V., \& Đokić, R. (2019). Cognitive Load in Multimedia Learning: An Example from Teaching about Lenses. Journal of Education in Science Environment and Health.

Dewi, N. M. J., Putra, D. K. N. S., \& Ganing, N. (2017). Pengaruh Model Pembelajaran Problem Based Learning Berbantuan Media Audio Visual Animasi Terhadap Hasil Belajar Ipa Universitas Pendidikan Ganesha. E-Journal PGSD Universitas Pendidikan Ganesha, 5(2), 1.

Dikmenli, Y., Danabaş, F., Çelík, B. B., \& Tekİn, Ö. (2018). Effects of Animation Film Use on Earthquake Knowledge Level of 4th Grade Students. Participatory Educational Research (PER), 5(1), 86-95.

Duskri, M., Sari, N. T., Negeri, I., Aceh, A. B., Darussalam, K., Aceh, B., \& Matematis, K. K. (2019). Penggunaan Model Pembelajaran Brain Based Learning Increasing Mts (Junior High School) Students ' Mathematical Communication Skills Through The Brain Keywords: Brain Based Learning Model, Mathematical Communication Ability Pendahuluan Tujuan Pembelaja. Jurnal Matematika Danpembelajaran., 7(1), 85-98.

ElAdl, A. M. (2019). Effect of brain-based learning program on working memory and academic motivation among the grade Omains students. International Journal of Psycho-Educational Sciences |, 8(1), 42-50.

Erhan, A. (2016). Observation of multimedia-assisted instruction in the listening skills of students with mild mental deficiency. Educational Research and Reviews, 11(5), 182-193.

Fitriani, A. (2019). Pengaruh Model Brain Based Learning Ditinjau dari Kemampuan Berpikir Kritis Siswa. Jurnal Pendidikan MIPA, Vol. 9, No.

Gowasa, S., Harahap, F., \& Suyanti, R. D. (2019). Perbedaan Penggunaan Media Powerpoint dan Video Pembelajaran terhadap Kemampuan Berpikir Tingkat Tinggi dan Retensi Memori Siswa pada Mata Pelajaran IPA di Kelas V Sd. Jurnal Tematik, 9(1), 19-27.

Hapsari, A. S., Hanif, M., Gunarhadi, \& Roemintoyo. (2019). Motion graphic animation videos to improve the learning outcomes of elementary school students. European Journal of Educational Research, 8(4), 1245-1255. 
Inocian, R. B. (2015). Integrated Arts-based Teaching (IAT) Model for Brain-based Learning. Journal of Curriculum and Teaching, 4(2), 130-143.

Jensen, E. (2011). Pembelajaran Berbasis-Otak Paradigma Pengajaran Baru. PT. Indeks.

Kaushal, R. K., \& Panda, S. N. (2019). A meta-analysis on effective conditions to offer an animationbased teaching style. Malaysian Journal of Learning and Instruction, 16(1), 129-153.

Khamin. (2018). Panduan Penilaian untuk Sekolah Dasar. Direktorat Pembinaan Sekolah Dasar Direktorat Jendral Pendidikan Dasar dan Menengah Kementrian Pendidikan dan Kebudayaan.

Koşar, G., \& Bedir, H. (2018). European Journal of Education Studies Improving Knowledge Retention Via Establishing Brain-Based Learning Environment. European Journal of Education Studies, Vol. 4, No.

Kristinawati, Devi, dkk. (2017). Implementasi Model Brain Based Learning Dengan Mind Map Pada Pembelajaran. 637-644.

Malkoc, U. (2017). Investigating teachers' understanding of the salt dissolution process: A multi-media approach in education. Turkish Online Journal of Educational Technology, 16(1), 55-71.

Purnama, F. (2016). Penerapan Model Brain Based Learning (BBL) Dalam Pembelajaran Matematika Untuk Meningkatkan Kemampuan Berpikir Kreatif Matematis Siswa SMP. Doctoral Dissertation, FKIP UNPAS, Vol 1, No.

Putu Santhi Widiasih, I. N. S. (2018). The Effect Of Brain-Based Learning On Second Grade Junior Students' Mathematics Conceptual Understanding On Polyhedron. Journal on Mathematics Education, 9(1), 145-156.

Rahayuni, G. (2016). Hubungan Keterampilan Berpikir Kritis Dan Literasi Sains Pada Pembelajaran Ipa Terpadu Dengan Model Pbm Dan Stm. Jurnal Penelitian Dan Pembelajaran IPA, 2(2), 131.

Rosita, I., \& Nur, D. (2016). Meningkatkan Kemampuan Berpikir Kreatif Matematis dan Kemandirian Belajar Siswa dengan Menggunakan Model Pembelajaran Brain Based Learning. Jurnal Pendidikan Unsika, 4(1), 26-41.

Salem, A. A. M. S. (2017). Engaging ESP Students with Brain-Based Learning for Improved Listening Skills, Vocabulary Retention, and Motivation. English Language Teaching, 10(12), 182.

Sani, A., Rochintaniawati, D., \& Winarno, N. (2019). Using Brain-Based Learning to Promote Students' Concept Mastery in Learning Electric Circuit. Journal of Science Learning, 2(2), 42.

Setiawan, D. W. (2019). The Influence of Active Learning on the Concept of Mastery of Sains Learning by Fifth Grade Students at Primary School. International Journal of Educational Methodology, 5(1), 189-194.

Shabatat, K., \& Al-Tarawneh, M. (2016). The Impact of a Teaching-Learning Program Based on a BrainBased Learning on the Achievement of the Female Students of 9th Grade in Chemistry. Higher Education Studies, 6(2), 162.

Sinar. (2018). Metode Active Learning Upaya Peningkatan Keaktifan dan Hasil Belajar Siswa. CV Budi Utama.

Sujana, A. (2014). Dasar-Dasar IPA: Konsep dan Aplikasinya. UPI Press.

Winter, R. (2019). The Benefit of Utilizing Brain-Based Learning in Higher Education Online Environments. Journal of Instructional Research, 8(1), 82-91.

Yasar, M. D. (2017). Brain-Based Learning in Science Education in Turkey: Descriptive Content and Meta-Analysis of Dissertations. Journal of Education and Practice, 8(9), 161-168. 